\title{
Pengaruh Karakteristik Perusahaan Terhadap Environmental Disclosure dalam Laporan Tahunan (Studi Pada Perusahaan Non Jasa yang Terdaftar Di Bursa Efek Indonesia)
}

\author{
Eko Hariyanto \\ Akuntansi, Fakultas Ekonomi dan Bisnis, Universitas Muhammadiyah Purwokerto \\ ekoh0361@gmail.com
}

\begin{abstract}
Abstrak
Tujuan dari penelitian ini adalah untuk menguji pengaruh ukuran perusahaan, profitabilitas, pencatatan saham dan kinerja lingkungan yang diukur dengan peringkat lingkungan perusahaan yang diberikan oleh Bapedal melalui program PROPER terhadap pengungkapan lingkungan. Hipotesisnya adalah bahwa ukuran perusahaan, profitabilitas, pencatatan saham, dan kinerja lingkungan berpengaruh signifikan terhadap pengungkapan lingkungan. Jenis penelitian ini adalah studi kasus pada perusahaan non keuangan yang listing di Bursa Efek Indonesia. Data tersebut merupakan data sekunder. Metode pengambilan sampel menggunakan purposive sampling, dengan sampel penelitian 66 dari 162 perusahaan non keuangan yang terdaftar. Alat analisis yang digunakan adalah regresi linier berganda. Hasil penelitian menunjukkan bahwa kinerja lingkungan mempunyai pengaruh positif yang signifikan terhadap pengungkapan lingkungan, tetapi ukuran perusahaan, profitabilitas, dan pencatatan saham gagal menunjukkan pengaruh yang signifikan.
\end{abstract}

Kata kunci : pengungkapan lingkungan, ukuran perusahaan, profitabilitas, bursa saham, listing dan kinerja lingkungan

\section{The Impact of Corporate Characteristics to Environmental Disclosure (Case Study At Non Financial Companies Listed In Indonesia Stock Exchange)}

\begin{abstract}
The aim of this research is to examine the impact of company size, profitability, stock exchange listing and environmental performance is measured by corporate environmental ratings provided by Bapedal through a program called PROPER to environmental disclosure. Its hyphotesis were that company size, profitability, stock exchange listing, and environmental performance having significant impact to environmental disclosure.The kind of this research was case study to the non-financial companies listing in Indonesia Stock Exchange. The data was secondary one. The sampling method used purposive sampling, with 66 of 162 non-financial companies listing as the sample research. To analyze it, multiple linear regression was used. The result indicated that environmental performance have a significant positive influence on the environmental disclosure, but company size, profitability, and stock exchange listing failed to show its significant impact.
\end{abstract}

Keywords : environmental disclosure, size company, profitability, stock exchange, listing and environmental performance.

\section{PENDAHULUAN}

Pembangunan dapat menjadikan kehidupan yang lebih baik, namun juga mengandung risiko pencemaran dan kerusakan lingkungan hidup. Untuk meminimalkan terjadinya pencemaran dan kerusakan tersebut, perlu diupayakan adanya keseimbangan antara pembangunan dengan kelestarian lingkungan (Suparmoko, 2010). Berubahnya kondisi lingkungan ekonomi banyak berpengaruh pada dunia usaha. Untuk dapat lebih bersaing, perusahaan dihadapkan pada kondisi untuk lebih transparan dalam mengungkapkan informasi perusahaannya. Informasi yang diungkapkan dalam laporan tahunan dapat dikelompokan menjadi dua, yaitu pengungkapan wajib (mandatory disclosure) dan pengungkapan sukarela (voluntary disclosure). 
Peraturan tentang standar pengungkapan informasi dalam laporan tahunan bagi perusahaan yang telah melakukan penawaran umum dan perusahaan publik, terakhir dikeluarkan oleh Bapepam tanggal 17 Januari 2006 yaitu peraturan nomor Kep-38 / PM / 2006. Penjelasan mengenai tanggung jawab lingkungan perusahaan dapat kita temukan pada pengungkapan sukarela (voluntary disclosure). Pada bagian inilah perusahaan mengungkapkan aktivitas operasinya yang berdampak pada lingkungan, serta kontribusi apa saja yang telah diberikan perusahaan terhadap lingkungan. Penelitian mengenai faktor-faktor yang memengaruhi environmental disclosure telah banyak dilakukan. Hackston \& Milne (2016) dalam penelitiannya menyimpulkan bahwa ukuran perusahaan dan tipe industri memengaruhi pengungkapan sosial dan lingkungan perusahaan. Hasil penelitian Fitriany (2001) menyatakan bahwa profitabilitas berpengaruh terhadap pengungkapan informasi sosial perusahaan. Dalam penelitiannya. Susi (2005) menyimpulkan umur listing perusahaan berhubungan signifikan dengan environmental disclosure. Suratno et al. (2006), menyatakan bahwa environmental performance berpengaruh positif dan signifikan terhadap environmental disclosure. Artikel ini membahas hasil penelitian yang menganalisis pengaruh karakteristik perusahaan terhadap environmental disclosure dalam laporan tahunan pada perusahaan non-jasa yang terdaftar di bursa efek indonesia.

\section{TINJAUAN PUSTAKA}

\section{Pengungkapan Tanggungjawab Lingkungan}

Pengungkapan tanggung jawab perusahaan terhadap lingkungan yang sering disebut juga environmental disclosure adalah pengungkapan informasi yang berkaitan dengan lingkungan dalam laporan tahunan perusahaan. Semakin banyak item environmental disclosure yang dimuat dalam laporan tahunan perusahaan, berarti semakin besar indeks environmental disclosure. Teoh et.al (1998) mengungkapkan 8 item tema pengungkapan lingkungan yang terbagi dalam empat kategori, yaitu:

1. Environmental Expenditure

a. Pengeluaran saat ini dan masa lalu

b. Perkiraan pengeluaran masa datang

2. Pengurangan polusi

a. Instalasi /sistem penanggulangan polusi

b. Pengendalian polusi (sesuai standar lingkungan)

3. Pelestarian Lingkungan

a. Konservasi SDA

b. Daur ulang

4. Informasi Lainnya

a. Perhatian perusahaan terhadap masalah lingkungan

b. Penghargaan untuk pelestarian lingkungan

\section{Karakteristik Perusahaan dan Environmental Disclosure Size Perusahaan}

Size perusahaan merupakan variabel penduga yang banyak digunakan untuk menjelaskan variasi pengungkapan dalam laporan tahunan perusahaan. Hal ini dikaitkan dengan teori agensi, di mana perusahaan besar yang memiliki biaya keagenan yang lebih besar akan mengungkapakan informasi yang lebih luas untuk mengurangi biaya keagenan tersebut. Pada penelitian Hackston \& Milne (1996) yang meneliti tentang faktorfaktor yang berpengaruh terhadap pengungkapan sosial dan pengungkapan lingkungan telah menemukan bahwa size perusahaan memengaruhi pengungkapan sosial dan lingkungan perusahaan. Berdasarkan asumsi teori agensi, maka penelitian ini mengajukan hipotesis sebagai berikut:

$$
H_{1} \text { : Size/ukuran perusahaan berpengaruh signifikan terhadap environmental disclosure }
$$

\section{Profitabilitas}

Perusahaan dengan tingkat profitabilitas yang tinggi dapat menunjukan bahwa perusahaan memiliki tingkat efektivitas dan efisiensi yang baik dalam menggunakan sumber daya yang dimilikinya dalam rangka mencapai target perusahaan yang telah ditetapkan. Profitabilitas menunjukan seberapa besar kemampuan perusahaan memperoleh laba, baik dalam hubungannya dengan penjualan, assets, maupun laba bagi modal sendiri. Hasil penelitian Fitriany (2001) menemukan bahwa, profitabilitas berpengaruh terhadap pengungkapan informasi sosial perusahaan, hal ini sesuai dengan teori keagenan yang menyatakan perusahaan dengan perolehan laba yang lebih besar akan menyediakan informasi sosial yang lebih luas. Pada penelitian ini akan mencoba meneliti pengaruh profitabilitas terhadap environmental disclosure yang 
merupakan bagian dari pengungkapan informasi sosial perusahaan. Atas penjelasan di atas, maka dapat dikemukakan hipotesis sebagai berikut:

$\mathrm{H}_{2}$ : Profitabilitas perusahaan berpengaruh signifikan terhadap environmental disclosure

\section{Umur Perusahaan}

IPO (Initial Public Offering) merupakan penawaran saham untuk pertama kalinya (Jogiyanto, 1998). Setelah perusahaan go public, maka perusahaan diwajibkan untuk mempublikasikan laporan hasil operasi perusahaan selama periode waktu tertentu. Pengungkapan informasi tersebut merupakan cara terbaik untuk menyeimbangkan kepentingan dan pengetahuan akan perusahaan antara manajer dengan pemilik. Semakin lama perusahaan melakukan IPO, diharapkan pengungkapan informasi yang dilakukan akan semakin luas pula. Susi (2005) menemukan bahwa umur listing perusahaan berhubungan signifikan dengan environmental disclosure. Penelitian ini mencoba menguji kembali pengaruh umur perusahaan listing di Bursa Efek Indonesia terhadap environmental disclosure dengan mengemukakan hipotesis sebagai berikut:

$H_{3}$ : Umur listing perusahaan berpengaruh signifikan terhadap environmental disclosure

\section{Environmental Performance}

Environmental performance adalah kinerja perusahaan dalam menciptakan lingkungan yang baik(green). Environmental performance perusahaan diukur dari prestasi perusahaan mengikuti PROPER (Program Penilaian Peringkat Kinerja Perusahaan dalam Pengelolaan Lingkungan Hidup) yang merupakan salah satu upaya yang dilakukan oleh Kementrian Lingkungan Hidup (KLH) untuk mendorong penataan perusahaan dalam pengelolaan lingkungan hidup melalui instrumen informasi. Peringkat kinerja PROPER menunjukan kinerja dan tindakan yang dilakukan perusahaan berkaitan dengan lingkungannya. Penelitian empiris mengenai hubungan environmental disclosure dan environmental performance telah menemukan hubungan yang beragam. Ingram dan Frazier (1980) dalam Suratno et al. (2016) telah manemukan tidak adanya hubungan yang signifikan dalam pengujian hubungan antara environmental disclosure dengan environmental performance. Sedangkan hasil penelitian Suratno et al. (2016), menyatakan bahwa environmental performance berpengaruh positif dan signifikan terhadap environmental disclosure. Atas dasar penjelasan di atas, maka peneliti mencoba menguji kembali pengaruh environmental performance terhadap environmental disclosure dengan mengemukakan hipotesis sebagai berikut:

\section{$H_{4}$ : Environmental performance berpengaruh signifikan terhadap environmental disclosure}

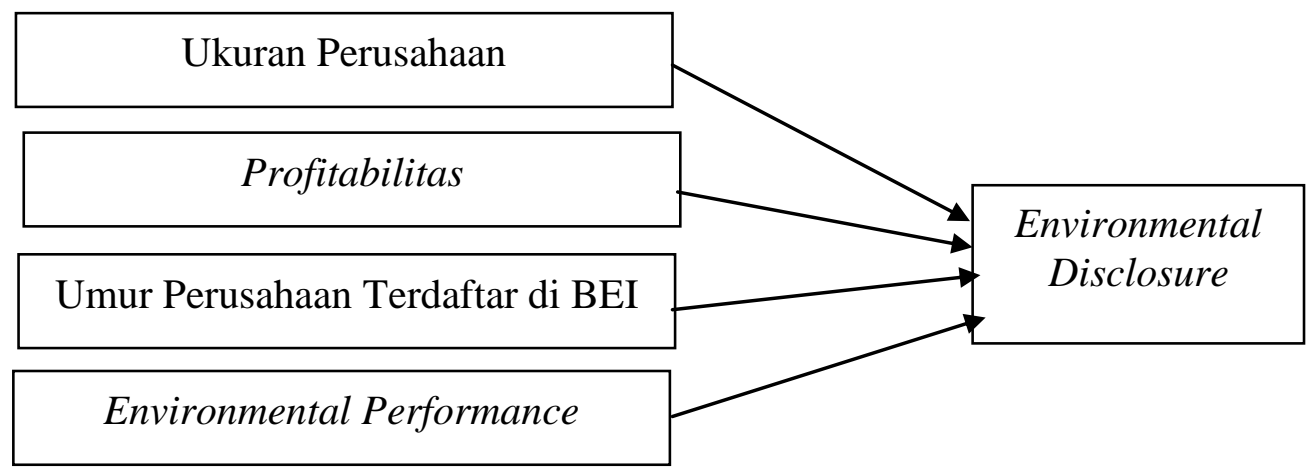

Gambar 1

Model Penelitian

\section{METODE PENELITIAN}

Populasi dalam penelitian ini adalah seluruh perusahaan non jasa yang terdaftar di BEI pada tahun 2015. Sampel penelitian ini diambil dengan teknik purposive sampling, dengan kriteria perusahaan menyampaikan laporan tahunan ke BAPEPAM pada tahun 2015, menerbitkan laporan keuangan tahunan (annual report) pada tahun 2015 dan mencantumkan environmental disclosure dalam laporan tahunan 2015. 


\section{Environmental Disclosure}

Environmental disclosure adalah pengungkapan informasi yang berkaitan dengan lingkungan di dalam laporan tahunan perusahaan. Pattern (2002) dalam Suratno (2016) mengidentifikasi cakupan delapan (8) item environmental disclosure yang digunakan dalam penelitian. Environmental disclosure perusahaan diukur dengan disclosure-scoring yang diperoleh dari analisis isi laporan keuangan dengan menggunakan metode skor yes/no (atau 1,0). Semakin banyak item environmental disclosure yang dimuat dalam laporan tahunan perusahaan, berarti semakin besar indeks environmental disclosure. Indeks pengungkapan lingkungan dirumuskan secara sistematis oleh Copeland dan Frederics (dalam Firmansyah, 2016) yang membagi jumlah skor item pengungkapan lingkungan perusahaan sampel terhadap jumlah seluruh item pengungkapan lingkungan.

\section{Size/Ukuran Perusahaan}

Dilihat dari total aktiva yang merupakan jumlah aktiva secara keseluruhan yang dimiliki oleh perusahaan, ditransformasikan dalam bentuk logaritma.

\section{Profitabilitas}

Profitabilitas diukur dengan menggunakan rasio net profit margin yang membagi rasio laba terhadap pendapatan.

\section{Umur Perusahaan}

Umur perusahaan diukur dengan lamanya perusahaan melakukan penawaran saham untuk pertama kalinya di Bursa Efek Indonesia (BEI) sampai dengan tanggal 31 Desember 2015.

\section{Environmental Perfomance}

Environmental performance perusahaan diukur dari prestasi perusahaan mengikuti program PROPER. Sistem peringkat kinerja PROPER mencakup pemeringkatan perusahaan dalam lima warna akan diberi skor secara berturut-turut dengan nilai tertinggi 5 untuk warna emas dan terendah 1 untuk warna hitam. Peringkat PROPER tersebut kemudian ditransformasikan dengan metode Successive interval (MSI). berikut:

Adapun persamaan untuk menguji hipotesis secara keseluruhan dalam penelitian ini adalah sebagai

$\mathrm{Y}=\mathrm{a}+b_{1} \mathrm{X}_{1}+b_{2} \mathrm{X}_{2}+b_{3} \mathrm{X}_{3}+b_{4} \mathrm{X} 4+\mathrm{e}$

Keterangan:

$\mathrm{Y}$ = Indeks skor pengungkapan lingkungan

$\mathrm{a}=$ Konstanta

$X_{1}=$ Logaritma natural dari total aktiva pada akhir tahun 2006

$\mathrm{X}_{2}=$ Rasio profitabilitas perusahaan

$\mathrm{X}_{3}=$ Umur perusahaan tarhitung sejak IPO hingga tahun 2006

$\mathrm{X} 4$ = Skor kinerja lingkungan

$b=$ Koefisien regresi masing-masing variable independen

e $\quad$ Kesalahan (error)

\section{HASIL DAN PEMBAHASAN}

Pengungkapan tanggung jawab lingkungan dapat dicari pada keseluruhan laporan tahunan perusahaan yang meliputi pendahuluan dalam laporan tahunan, profil perusahaan, surat dari dewan direksi dan dewan komisaris yang terdiri dari kata sambutan, analisis kondisi perusahaan di masa yang akan datang, catatan atas laporan keuangan, serta diskusi dan analisis manajemen perusahaan. Dari keseluruhan perusahaan non jasa yang listing di BEI tahun 2015 hanya 66 perusahaan yang memenuhi kriteria sampel penelitian, sampel tersebut diperoleh setelah peneliti melakukan checklist atas laporan tahunan (annual report) perusahaan. 


\section{Uji Asumsi Klasik}

\section{Uji Normalitas}

Hasil pengujian dengan normal probability plot of standardized residual menunjukan bahwa titiktitik menyebar disekitar garis diagonal, maka dapat dikatakan bahwa penyebaran data mendekati normal atau memenuhi asumsi normalitas. Hal ini didukung dengan hasil uji Kolmogorov-Smirnov yang menunjukkan nilai Asyimp.sig.(2-tailed) 0,283 >0,05 (alpha).

\section{Uji Heteroskedastisitas}

Hasil perhitungan menggunakan metode Park Gleyser diperoleh nilai signifikansi masing-masing variabel independen lebih dari 0,05 (alpha). Hal ini menunjukan bahwa dalam model tidak terdapat gejala heteroskedastisitas.

\section{Uji Multikolinearitas}

Hasil pengujian menunjukkan tidak ada nilai tolerance yang kurang dari 10\%. Demikian juga hasil perhitungan VIF yang menunjukkan tidak ada satupun variabel independen yang memiliki nilai VIF lebih dari 5. Maka dapat disimpulkan bahwa tidak terjadi gejala multikolinieritas dalam model.

\section{Uji Autokorelasi}

Model tidak terjadi autokorelasi jika nilai Durbin Watson hitung terletak di daerah No Autokorelation. Nilai dari hasil pengujian Durbin Watson adalah 1,680. Setelah melihat tabel Durbin Watson dan menghitungnya ternyata nilai tersebut berada di daerah tidak ada autokorelasi.

\section{Pengujian Hipotesis}

Tabel 1

Model Summary

\begin{tabular}{l|c|r|r|c}
\hline Model & R & R Square & $\begin{array}{c}\text { Adjusted } R \\
\text { Square }\end{array}$ & $\begin{array}{c}\text { Std. Error of the } \\
\text { Estimate }\end{array}$ \\
\hline 1 & .427 (a) & .182 & .128 & .191531 \\
\hline
\end{tabular}

Sumber : Data diolah, 2020

Tabel 2

Hasil Uji Simultan

\begin{tabular}{llrrrrr}
\hline Model & & $\begin{array}{c}\text { Sum of } \\
\text { Squares }\end{array}$ & df & Mean Square & \multicolumn{1}{c}{ F } & \multicolumn{1}{c}{ Sig. } \\
\hline 1 & Regression & .498 & 4 & .125 & 3.394 & $.014(\mathrm{a})$ \\
\hline & Residual & 2.238 & 61 & .037 & & \\
\hline & Total & 2.736 & 65 & & & \\
\hline
\end{tabular}

Sumber : Data diolah, 2020

Tabel 3

Hasil Pengujian Regresi Variabel Size, Profitabilitas, Umur Perusahaan, dan Environmental Performance terhadap Environmental Disclosure

\begin{tabular}{|c|c|c|c|c|c|c|}
\hline \multirow[b]{2}{*}{ Model } & & \multicolumn{2}{|c|}{$\begin{array}{l}\text { Unstandardized } \\
\text { Coefficients }\end{array}$} & \multirow{2}{*}{$\begin{array}{c}\begin{array}{c}\text { Standardized } \\
\text { Coefficients }\end{array} \\
\text { Beta } \\
\end{array}$} & \multirow[b]{2}{*}{$\mathbf{t}$} & \multirow[b]{2}{*}{ Sig. } \\
\hline & & B & Std. Error & & & \\
\hline 1 & (Constant) & .339 & .085 & & 3.968 & .000 \\
\hline & Size & .001 & .006 & .017 & .145 & .886 \\
\hline & Profitabilitas & .010 & .068 & .017 & .145 & .885 \\
\hline & Umur Perusahaan & -.005 & .004 & -.142 & -1.225 & .225 \\
\hline & Env. Performance & .058 & .017 & .399 & 3.387 & .001 \\
\hline
\end{tabular}

Sumber : Data diolah, 2020 
Hipotesis dalam penelitian ini bertujuan untuk mengetahui pengaruh variabel ukuran perusahaan, profitabilitas, umur perusahaan, dan environmental performance terhadap variabel dependen environmental disclosure dengan menggunakan analisis regresi linear berganda. Ringkasan hasil pengujian tersebut adalah seperti dalam tabel pada tabel 1. Berdasarkan tabel 1, hasil perhitungan R square sebesar 0,182 atau $18,2 \%$ berarti perubahan tingkat pengungkapan informasi lingkungan hidup dapat dijelaskan oleh size perusahaan, profitabilitas, umur perusahaan dan environmental performance sedangkan sisanya, yaitu sebesar $81,8 \%$ dijelaskan oleh faktor lain yang tidak diteliti dalam penelitian ini. Hasil pengujian berdasarkan tabel 2 juga menunjukkan bahwa secara simultan variabel size perusahaan, profitabilitas, umur perusahaan, dan environmental performance berpengaruh signifikan secara statistik berdasarkan nilai $\mathrm{F}_{\text {hitung }}$ sebesar 3,394 lebih besar dari nilai dari $\mathrm{F}_{\text {tabel }}$ (dengan $\alpha=0,05 ; \mathrm{df}_{1}=3$ dan $\mathrm{df}_{2}=62$ ) sebesar 2,75.

Dari tabel 3 juga dapat dilihat bahwa nilai $t_{\text {hitung variabel size perusahaan, profitabilitas, dan umur }}$ perusahaan masing-masing sebesar 0,$145 ; 0,145$ dan $-1,225$ lebih kecil dari tabel $(2,000)$ dan $\rho>0,05$ sehingga dapat diartikan bahwa ketiga variabel tersebut tidak berpengaruh signifikan terhadap tingkat pengungkapan informasi lingkungan hidup (environmental disclosure). Nilai thitung variabel environmental performance sebesar 3,387 lebih besar dari $t_{\text {tabel }}(2,000)$ dan $\rho<0,05$ sehingga dapat diartikan bahwa terdapat pengaruh positif yang signifikan dari variabel environmental performance terhadap tingkat pengungkapan informasi lingkungan hidup (environmental disclosure). Dalam pengujian secara parsial hanya variabel environmental performance yang berpengaruh signifikan terhadap tingkat pengungkapan informasi lingkungan hidup (environmental disclosure), sedangkan variabel size perusahaan, profitabilitas, umur perusahaan tidak mempunyai pengaruh yang signifikan terhadap environmental disclosure.

\section{Environmental performance}

Hasil penelitian ini mendukung penelitian yang dilakukan oleh Suratno et al. (2016) yang menemukan bahwa environmental performance berpengaruh positif dan signifikan terhadap environmental disclosure. Hal ini konsisten dengan model discretionary disclosure menurut Verrecchia dalam Suratno et al. (2016) bahwa perusahaan yang memiliki environmental performance yang baik merupakan good news bagi investor dan calon investor, sehingga perusahaan dengan environmental performance yang baik mengungkapkan lebih banyak informasi lingkungan hidup dibanding perusahaan dengan environmental performance yang lebih buruk.

\section{Size Perusahaan}

Hasil penelitian ini tidak konsisten dengan penelitian yang dilakukan oleh Hackston \& Milne (1996) serta Fitriany (2001) yang menemukan bahwa size mempengaruhi pengungkapan sosial dan lingkungan perusahaan. Dalam penelitian yang dilakukan oleh Hackston \& Milne (1996) serta Fitriany (2001) lebih cenderung size perusahaan berpengaruh terhadap pengungkapan sosial secara keseluruhan. Dalam hal ini perusahaan kecil umumnya berada pada situasi persaingan yang ketat dengan perusahaan yang lain. Mengungkapkan terlalu banyak tentang jati dirinya kepada pihak eksternal dapat membahayakan posisinya dalam persaingan, sehingga perusahaan kecil cenderung untuk tidak melakukan pengungkapan selengkap perusahaan besar. Penjelasan yang memungkinan adalah tidak terdapat perbedaan bagi perusahaan yang memiliki total asset yang besar dan perusahaan dengan total asset kecil dalam pengungkapan informasi lingkungan hidup (environmental disclosure), karena mengungkapkan informasi lingkungan hidup tidak akan membahayakan posisi suatu perusahaan dalam persaingan.

\section{Profitabilitas}

Hasil analisis dengan menggunakan variabel profitabilitas dalam penelitian ini konsisten dengan penelitian yang dilakukan oleh Hackston \& Milne (1996) yang menemukan bahwa profitabilitas tidak berpengaruh terhadap tingkat pengungkapan sosial dan lingkungan (environmental disclosure). Padahal menurut teori keagenan, perusahaan dengan perolehan laba yang lebih besar akan menyediakan informasi sosial yang lebih luas. Hasil penelitian ini tidak menunjukan hal tersebut karena mungkin ketika perusahaan memiliki tingkat laba yang tinggi, perusahaan (manajemen) menganggap tidak perlu melaporkan hal-hal yang dapat mengganggu informasi tentang kesuksesan keuangan yang diraih perusahaan. Sebaliknya, pada saat tingkat profitabilitas rendah, para pengguna laporan akan memperhatikan laporan kinerja perusahaan salah satunya perhatian perusahaan terhadap lingkungan.

\section{Umur Perusahaan}

Umur perusahaan terdaftar di BEI tidak berpengaruh terhadap tingkat pengungkapan informasi lingkungan hidup (environmental disclosure). Sehingga tidak konsisten dengan penelitian yang dilakukan 
oleh Susi (2005) yang menemukan bahwa umur listing perusahaan berpengaruh terhadap tingkat pengungkapan informasi lingkungan hidup. Penjelasan yang mungkin adalah tidak menutup kemungkinan perusahaan yang berumur lebih muda lebih banyak melakukan pengungkapan informasi lingkungan hidup dibandingkan dengan perusahaan yang berumur lebih tua. Hal ini berhubungan dengan kesadaran masingmasing perusahaan dalam memperhatikan masalah lingkungan dan mengungkapkan informasi lingkungan hidup.

\section{PENUTUP}

Penelitian ini menemukan bahwa ukuran perusahaan, profitabilitas, umur perusahaan, dan environmental performance secara simultan berpengaruh signifikan terhadap tingkat pengungkapan informasi lingkungan hidup serta secara parsial environmental performance berpengaruh signifikan terhadap tingkat pengungkapan informasi lingkungan hidup. Di sisi lain penelitian ini tidak menemukan pengaruh yang signifikan secara parsial variabel ukuran perusahaan, profitabilitas, dan umur perusahaan terhadap tingkat pengungkapan informasi lingkungan hidup.

Sampel yang digunakan hanya tahun 2015 karena adanya keterbatasan dari peneliti untuk mendapatkan data dan hanya perusahaan non-jasa saja, hal ini dikarenakan hanya industri non-jasa saja yang berpeluang menghasilkan polusi. Namun tidak menutup kemungkinan pengungkapan informasi lingkungan hidup juga dilaksanakan oleh industri jasa, seperti jasa konstruksi, jasa properti dan jasa transportasi. Adanya unsur subyektifitas dalam mengukur luas pengungkapan informasi lingkungan hidup dalam laporan tahunan. Hal ini mengakibatkan perbedaan penilaian antar perusahaan yang dijadikan sampel penelitian.

\section{DAFTAR PUSTAKA}

Anggraini, Fr. Reni Retno. 2016. Pengungkapan Informasi Sosial dalam Laporan Keuangan Tahunan (Study Empiris pada Perusahaan-perusahaan yang Terdaftar di Bursa Efek Jakarta). Simposium Nasional Akuntansi IX.

Bhuono Agung Nugraha. 2005, Strategi Jitu Memilih Metode Statistik Penelitian dengan SPSS. Edisi Pertama, C.V. ANDI, Yogyakarta.

Fitriany. 2001. Signifikansi Perbedaan Tingkat Kelengkapan Pengungkapan Wajib dan Sukarela pada Laporan Keuangan Perusahaan Publik yang Terdaftar di BEJ. Simposium Nasional Akuntansi IV.

Hackston David dan Markus J. Milne. 2016. Some Deterninants of social and Environmental Disclosure in New Zealand Companies. Accounting, Auditing and Accountability Journal, Vol. 9 No. 12016.

Henny dan Murtanto. 2011. Analisis Pengungkapan Sosial pada Laporan Tahunan. Media Riset Akuntansi, Auditing dan Informasi, Vol. 1 No. 2, Agustus 2001.

Marwata. 2001. Hubungan antara Karakteristik Perusahaan dan Kualitas Ungkapan Sukarela dalam Laporan Tahunan Perusahaan Publik di Indonesia. Simposium Nasional Akuntansi IV.

Sembiring Eddy Rismanda. 2005. Karakteristik Perusahaan dan Pengungkapan Tanggung jawab Sosial. Simposium Nasional Akuntansi VIII.

Suparmoko, M dan Maria R. Suparmoko. 2010, Ekonomika Lingkungan. Cetakan ketiga, BPFE, Yogyakarta.

Suratno Ignatius Bondan dan Darsono. 2016. Pengaruh Environmental Performance terhadap Environmental Disclosure dan Economic Performance. Simposium Nasional Akuntansi IX.

Susi. 2005. The Relationship Between Environmental Performance and Financial Performance Amongst Indonesian Companies. Simposium Nasional Akuntansi VIII.

Yuniati Gunawan. 2011. Analisa Tingkat Pengungkapan Laporan Tahunan pada Perusahaan yang Terdaftar di Bursa Efek Jakarta. Media Riset Akuntansi, Auditing dan Informasi, Vol. 1 No. 2, April 2011. 